\title{
Association of some dietary ingredients, vitamin $D$, estrogen, and obesity polymorphic receptor genes with bone mineral density in a sample of obese Egyptian women
}

\author{
Nayera E. Hassan ${ }^{1}$, Salwa M. El Shebini², Sahar A. El-Masry ${ }^{1 *}$ (D, Nihad H. Ahmed², Ghada Nour Eldeen²,
} Enas A. Rasheed ${ }^{4}$, Manal M. Aly ${ }^{1}$, Khhadija M. Alian', Mahmoud A S. Afify ${ }^{1}$ and Aya Khalii ${ }^{1}$

\begin{abstract}
Background: Although many environmental factors play an important role in bone mass density (BMD) variation, genetic influences account for $60-85 \%$ of individual variance. The aim of this study was to find the interaction between some dietary ingredients, vitamin D, estrogen, and obesity polymorphic receptor genes, among a sample of obese Egyptian women. This was a cross sectional study included 97 women (aged 25-60 years). Data on anthropometry, dietary intake, BMD, biochemical, and genetic analyses were collected.

Results: Osteoporosis was high among women had dominant Taq1 vitamin D receptor gene while osteoporosis was less common among the homozygous Apa1 receptor gene women. Both genes in their two forms did not show any effect on serum vitamin D. Heterozygous types of osteoporotic women carried both genes revealed a slight but significant decrease in level of serum calcium. Xba1 estrogen receptor gene was identified only in a homozygous type while the heterozygous Pvu11 estrogen receptors gene has been identified among both osteoporotic and non-osteoporotic women, this gene was associated with higher BMI in both groups compared to the homozygous receptor gene. Mutant types of genotype FTOrs 99 and FTOrs80 obesity receptors genes were less common $(4.44 \%, 11 \%)$ among participants. Both of these genes were associated with the highest value of BMI and caloric daily intake, fat, and saturated fatty acid that were more prominent among osteoporotic women.

Conclusion: There is significant association between vitamin D, estrogen, obesity receptors genes, special nutrients, and osteoporosis. Increased BMI, calories, and fat intake lead to rise of genetic predisposition and susceptibility to osteoporosis.
\end{abstract}

Keywords: Osteoporosis, Vitamin D receptors genes, Estrogens receptors genes, Obesity receptors genes, Dietary intake

\footnotetext{
* Correspondence: masrysa@yahoo.com

'Biological Anthropology Department, Medical Research Division, National

Research Centre, Giza, Egypt

Full list of author information is available at the end of the article
}

\section{Springer Open}

(c) The Author(s). 2021 Open Access This article is licensed under a Creative Commons Attribution 4.0 International License, which permits use, sharing, adaptation, distribution and reproduction in any medium or format, as long as you give appropriate credit to the original author(s) and the source, provide a link to the Creative Commons licence, and indicate if changes were made. The images or other third party material in this article are included in the article's Creative Commons licence, unless indicated otherwise in a credit line to the material. If material is not included in the article's Creative Commons licence and your intended use is not permitted by statutory regulation or exceeds the permitted use, you will need to obtain permission directly from the copyright holder. To view a copy of this licence, visit http://creativecommons.org/licenses/by/4.0/. 


\section{Background}

The osteoporosis etiology is considered to be multifactorial related to polygenic background which can be modulated by integrated effects of genetic, hormonal, environmental and nutritional factors. Despite the fact that several environmental factors present an important role in the variation of bone mass density (BMD), the influence of genetic factors account for $60-85 \%$ of individual variance. However, genetic studies show that candidate genes are included in the BMD variation and also in the progression of osteoporosis $[1,2]$.

Vitamin D deficiency may be related to several factors as the exposure to sunlight and nutrition deficiency, in addition to race, age, sex, obesity, and impaired synthesis of vitamin D and its metabolism [3]. Vitamin D is obtained from same limited dietary sources and is derived from cutaneous synthesis upon sunlight exposure [4]. Throughout a multistep process that is highly regulated, vitamin $\mathrm{D}$ is metabolized to 1 , 25-dihydroxyvitamin $\mathrm{D}$ which is a key hormone for regulating calcium homeostasis [4]. The hormone 1,25 dihydroxy vitamin D helps to regulate the gene expression that happens after being bonded to vitamin D receptor (VDR). It is a classic nuclear hormone receptor which is commonly expressed through all the body tissues $[5,6]$.

However, estrogen is known to be the key regulator hormone for bone metabolism in both women and men. Menopause which is accompanied by the loss of ovarian estrogens is associated with the decline in bone mineral density (BMD) [7]. The polymorphism that occurs to estrogen receptor genes (ESR1, ESR2) appears to be important among genetic factors [8]. Consequently, the gene encoding estrogen receptor 1 ; which is one of the two mediators of the action of estrogen; is considered to be an essential candidate in order to determine the risk of osteoporosis $[9,10]$. Moreover, the associations of BMD and estrogen receptor polymorphisms in addition to lipids are incompatible [11].

Controversial findings have shown in different studies, regarding obesity impact on the bone metabolism. Salamat and his colleagues [12] revealed that obesity, that is defined by BMI, confirmed low BMD and decreased osteoporosis risk in a non-institutionalized population. Both lean mass and body fat were suggested to assist in BMD maintenance which occurs by generating mechanical overload on the bones [13, 14]. However, it was evident recently that sarcopenic obesity, which is a term that refers to the presence of increased body fat and decreased muscle mass, was reported to be accompanied with osteoporosis development among elderly population $[15,16]$. The genome-wide associations studies (GWASs) have successfully identified loci which is associated with obesity and osteoporosis. There are also seven potentially pleiotropic genes had been identified to be associated with obesity and osteoporosis. The result of research's and findings can provide recent insight into potential genetic determination and the codetermination mechanism of obesity and osteoporosis [17].

The objective of this study was to find the interaction between some dietary ingredients; and vitamin D, estrogen, and obesity polymorphic receptor genes, among a sample of obese Egyptian women.

\section{Methods}

This cross-sectional study included 97 Egyptian obese women (with age range 25-60 years, and mean age $48.85+9.88$ years.). They were recruited and randomly chosen, from all employees and workers of all categories of the "Blinded for peer review". They were classified according to their BMD-t score into 2 groups: osteoporotic $(n=52)$ and non-osteoporotic $(n=45)$. A written informed consent was obtained from all participants after being informed about the purpose of the study. This research paper was derived from a cross-sectional survey of a project funded by Blinded for peer review, 20162019 entitled "Bone mass among Overweight and Obese Women: Mechanism and Intervention." (Blinded for peer review), with an approval obtained from Ethics Committee of Blinded for peer review (Registration Number is 16/127).

The following parameters, anthropometric measurements, DEXA, laboratory and genetic investigations, and dietary intake were assessed for all participants.

\section{Anthropometric measurements}

Body weight and height were measured, following the recommendations of the "International Biological Program" [18]. Body weight (Wt) was determined to the nearest $0.01 \mathrm{~kg}$ using a Seca Scale Balance, with the participant wearing minimal clothes and with no shoes. Body height $(\mathrm{Ht})$ was measured to the nearest $0.1 \mathrm{~cm}$ using a Holtain portable anthropometer. Body mass index [BMI: weight (in kilograms) divided by height (in meters squared)], was calculated.

\section{DEXA measurements}

Bone mineral density "BMD" $\left(\mathrm{gm} / \mathrm{cm}^{2}\right)$ at the neck of femur were measured using dual-energy DEXA (DEXA Norland XR-46 version 3.9.6/2.3.1, USA). Full body DEXA scan, based on the woman's age, weight, and height, was performed with the participant keeping the precise distance between her arms and legs according to the machine instructions manual. A well-qualified operator executed and evaluated all analyses using the same protocol for all assessments. The instruments were calibrated daily according to the manufacturer's instructions. Osteoporosis is established by measurement of BMD at the neck of femur using the $T$ score which was 
calculated using the following formula: $T$ score $=($ measured bone density-maximum bone density)/the maximum standard deviation;

if $T$ score $\geq-1.0$ was grouped as normal, $T$ score $<-$ 1.0 to $>-2.5$ was put in the osteopenia and $T$ score $\leq-$ 2.5 were categorized as having osteoporosis following the diagnostic criteria established by the World Health Organization [19] in adults. All participated women were divided into two groups: normal and osteopenia (45 non-osteoporotic) and 52 osteoporosis according to their bone health status.

\section{Laboratory investigations}

After overnight $8 \mathrm{~h}$ fasting, participants' venous blood samples were obtained by venipuncture in the morning to assess the following parameters: serum calcium $(\mathrm{Ca})$ and serum 25 hydroxy vitamin-D. The blood samples that were left to clot were then centrifuged at $5000 \mathrm{rpm}$ for $10 \mathrm{~min}$ to separate sera; that were then stored at $80{ }^{\circ} \mathrm{C}$ to be assayed later on. The assessments of these parameters were done in the laboratory of "Medical Excellence Research Center MERC", which is part of "Blinded for peer review".

Serum calcium level was measured using the automated clinical chemistry analyzer Olympus AU 400 analyzer [20]. Serum 25 hydroxy vitamin-D (25 (OH) D) was assessed by ELISA kit, for vitamin D Catalogue number SL1831 HU.Sun long Biotech.Co. Ltd. [21].

\section{Genetic investigations}

\section{Extraction of genetic material and polymorphisms analysis}

DNA was extracted from the blood samples by using QIAamp DNA mini kit (QIAGEN, Germany). The presence of PvuII and XbaI polymorphisms (Fig. 1) within the ESR gene were analyzed using polymerase chain reaction-restriction fragment length polymorphism (PCR-RFLP). The oligonucleotide primers used to determine the PvulI and XbaI polymorphisms included forward primer, 5 '-CTG CCA CCC TAT CTG TAT CTT TTC CTA TTC TCC- 3'; and reverse primer, 5'-TCT TTC TCT GCC ACC CTG GCG TCG ATT ATC TGA$3^{\prime}$. PCR reactions were performed through 30 cycles by the following: $50 \mathrm{~s}$ at $95{ }^{\circ} \mathrm{C}$ (denaturation), $50 \mathrm{~s}$ at $62{ }^{\circ} \mathrm{C}$ (annealing), $50 \mathrm{~s}$ at $72{ }^{\circ} \mathrm{C}$ (extension), and final extension for $7 \mathrm{~min}$ at $72{ }^{\circ} \mathrm{C}$ to ensure a complete extension of all PCR products.

All the included cases were genotyped using PCRRFLP for two restriction sites in the VDR gene; ApaI (rs7975232) (A/C) in intron 8 (Fig. 2) and TaqI (rs731236) (A/G) in exon 9 (Fig. 3) using specific primer sequences; these primers were forward: 5'GGGATGGACAGAGCATGG3' and reverse: 5'CCACCTCCCCTATCCACC3. Genomic DNA was amplified using the following: initial denaturation at $94{ }^{\circ} \mathrm{C}$ for $10 \mathrm{~min}$, and 30 cycles of denaturation at $94{ }^{\circ} \mathrm{C}$ for $1 \mathrm{~min}$, annealing at $64{ }^{\circ} \mathrm{C}$ for $1 \mathrm{~min}$ and extension at $72{ }^{\circ} \mathrm{C}$ for $1 \mathrm{~min}$, followed by final extension at $72{ }^{\circ} \mathrm{C}$ for $10 \mathrm{~min}$.

\section{Post-PCR-RFLP}

The resulting DNA fragments were subjected to restriction digestion using the respective enzymes. The genotypes were resolved on 3\% (w/v) agarose gels. Genotypes were designated conventionally by the first letter of the name of the enzyme. Capital letter indicates the absence of the cut site, whereas lower case letter indicates its presence.

The FTO rs9939609 and rs8050136 SNPs were genotyped by the Taqman assay (ABI: Applied Biosystems, Foster City, USA). The primers and probes of SNPs were from ABI assay on demand kit. Reactions were carried out according to the manufacturer's protocol. The probe fluorescence signal detection was performed using the ABI Prism 7900 real-time PCR system.

\section{Dietary intake}

Detailed data about nutritional habits and intake through: 24 recall diet history was collected. Analysis of food items, particularly calcium, vitamin $\mathrm{D}$, and fat (saturated, mono, and poly unsaturated fat) intake, was done using World Food Dietary Assessment System, (WFDAS) [22], USA, University of California.

\section{Statistical analysis}

Data were analyzed using the Statistical Package for Social Sciences (SPSS/Windows Version 22, SPSS Inc., Chicago, IL, USA). Normality of data was tested using

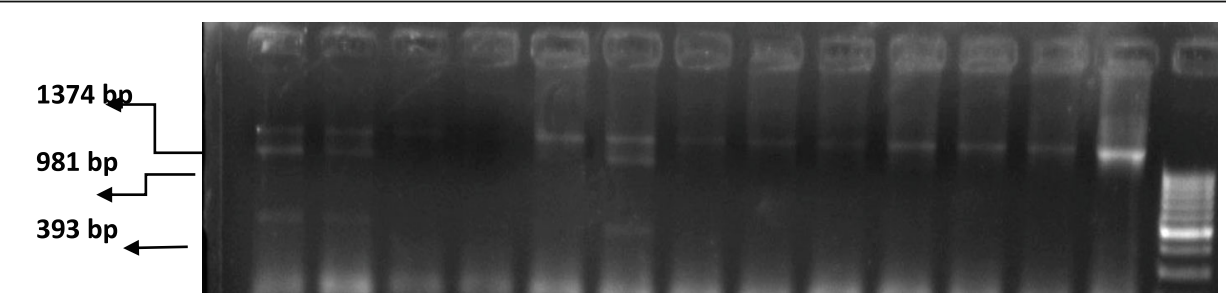

Fig. 1 Detection of Xba1 polymorphism. PCR and digestion products. Lanes 1, 2, and 6: X/X genotype (1374, 981, and 393 bp). Lanes 3, 4, 5, 7, 8, 9, 10, 11, and 12: X/X genotype (1374 bp). Lane 13: the PCR amplified product (1374 bp). M: DX 174 marker/Hae III digest 


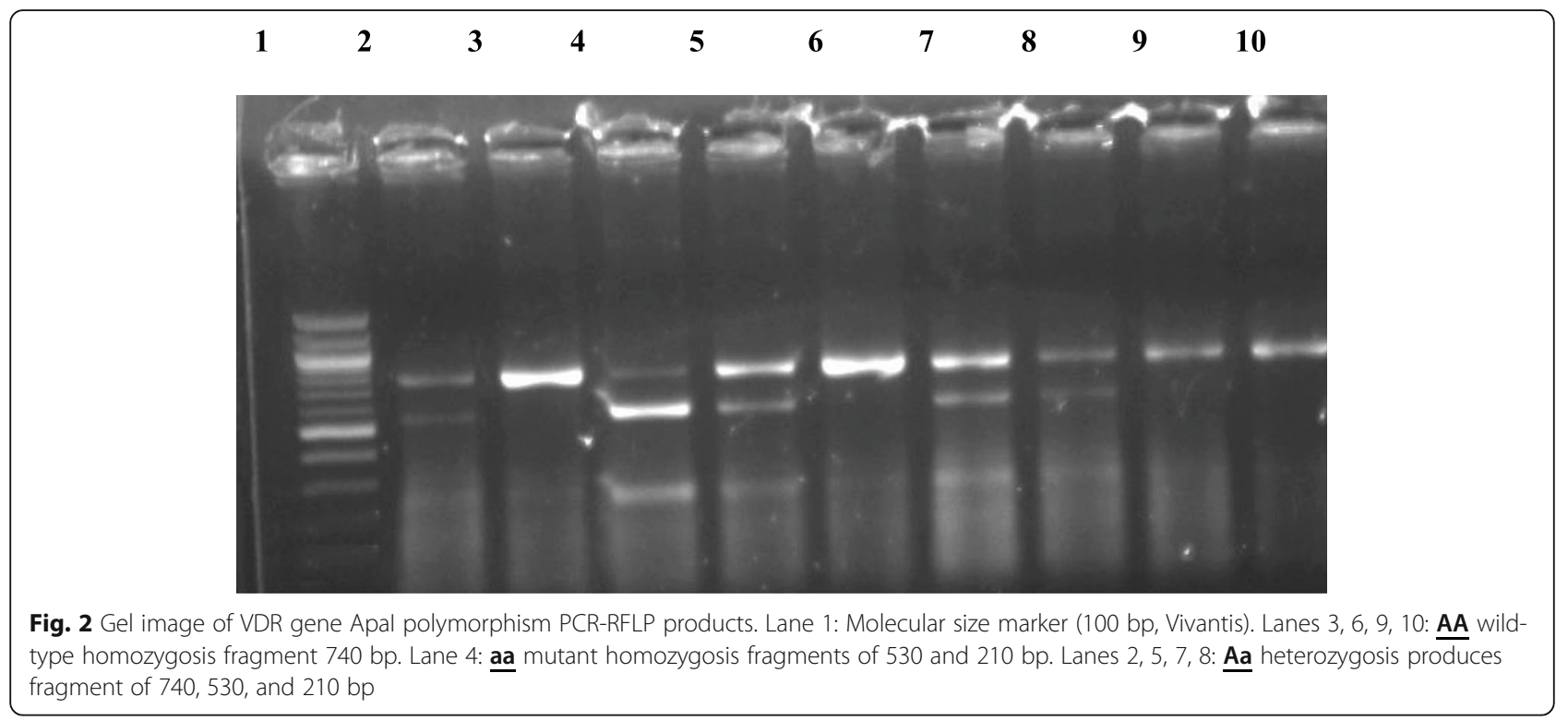

the Kolmogorov-Smirnov test. Some of the variables, such as the data of DEXA, weight, BMI, and calcium intake were not normally distributed.

The parametric data were expressed as mean $\pm \mathrm{SD}$, where the qualitative ones were expressed as number and percentage (\%). The distribution of the women and the type of gene for the 2 groups were analyzed and compared using chi-square test for independent groups. Student's $t$ test was used to compare between 2 parametric groups. While ANOVA test was used to compare between 3 parametric groups. $P$ value $<0.05$ was regarded as statistically significant for all tests.

\section{Results}

Distribution of women by the type of vitamin D, estrogen, and of obesity polymorph receptor genes are showed in Table 1. Osteoporosis was high among women had dominant Taq1 vitamin D receptor gene
(65.38\%), while the homozygousApa1 receptor gene might give a sort of protection against osteoporosis (80.0\% of non-osteoporotic). No mutant Xba1 and Pvu11 estrogen receptor genes were detected among the studied sample, while the homozygous Xba1 was identified among all the participants. Distribution of the homozygous Pvul1 was higher among nonosteoporotic women while the heterozygousPvu11 have been identified at higher level among osteoporotic women. Both the genotype FTOrs99 and FTOrs80 obesity receptor genes were detected among non-osteoporotic and osteoporotic women with slight insignificant difference. The mutant types were less common, $4.44 \%$ and $11.54 \%$ among non-osteoporotic and osteoporotic women respectively. However, insignificant differences between the two non-osteoporotic and osteoporotic groups regarding the distribution of different genotypes were found.

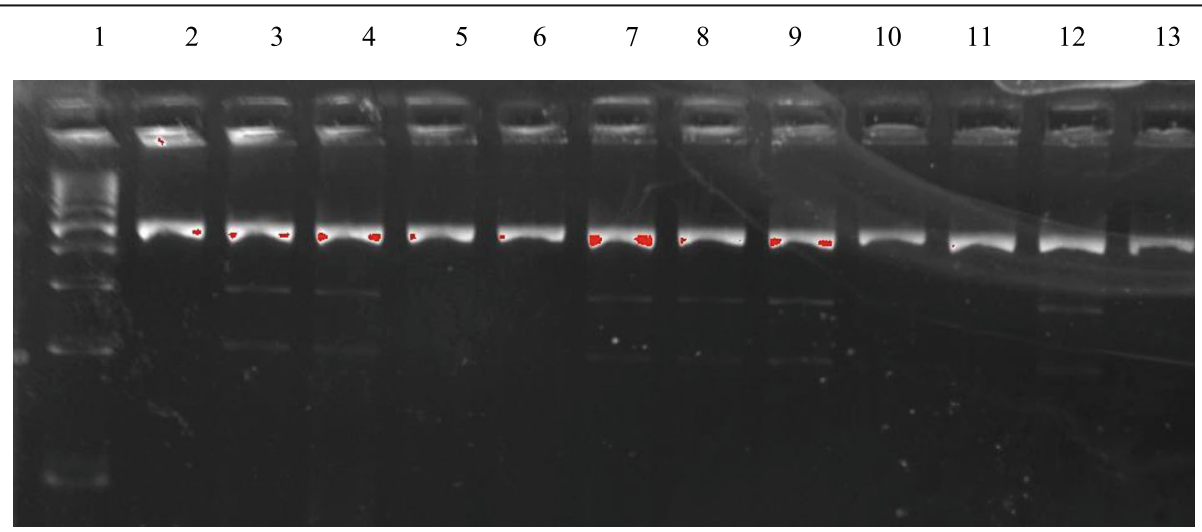

Fig. 3 Gel image of VDR gene Taql polymorphism PCR-RFLP products. Lane 1: Molecular size marker (100 bp, Vivantis). lanes 2, 5, 6, 10, 11,13: TT wild- type homozygosis produces fragments of $495 \mathrm{bp}$. lanes 3, 4, 7, 8, 9,12: Tt heterozygosis produces fragments of 495, 290, and 205 bp 
Table 1 Distribution of genotypes of vitamin D receptors, estrogen receptors, and obesity receptors in studied nonosteoporotic and osteoporotic women

\begin{tabular}{|c|c|c|c|}
\hline Parameters & $\begin{array}{l}\text { Non-osteoporotic } \\
N=45 \\
\% 46.39\end{array}$ & $\begin{array}{l}\text { Osteoporotic } \\
N=52 \\
\% 53.61 \\
\end{array}$ & $\begin{array}{l}\text { Chi-square } \\
P\end{array}$ \\
\hline \multicolumn{4}{|c|}{ Taq1 vit. D receptor gene } \\
\hline Homozygous & $26(57.78 \%)$ & $34(65.38 \%)$ & 0.442 \\
\hline Heterozygous & $19(42.22 \%)$ & $18(34.62 \%)$ & \\
\hline Mutant & $0.0(0.0 \%)$ & $0.0(0.0 \%)$ & \\
\hline \multicolumn{4}{|c|}{ Apa1 vit. D receptor gene } \\
\hline Homozygous & $36(80.0 \%)$ & $33(63.46 \%)$ & 0.162 \\
\hline Heterozygous & $9(20.0 \%)$ & $18(34.62 \%)$ & \\
\hline Mutant & $0(0.00 \%)$ & $1(1.92 \%)$ & \\
\hline \multicolumn{4}{|c|}{ Xba1 estrogen receptor gene } \\
\hline Homozygous & 45 (100\%) & $52(100 \% 0)$ & ------ \\
\hline Heterozygous & 0.0 & 0.0 & \\
\hline Mutant & 0.0 & 0.0 & \\
\hline \multicolumn{4}{|c|}{ Pvu11 estrogen receptor gene } \\
\hline Homozygous & $32(71.11 \%)$ & $35(67.31 \%)$ & 0.686 \\
\hline Heterozygous & $13(28.89 \%)$ & $17(32.69 \%)$ & \\
\hline Mutant & 0.0 & 0.0 & \\
\hline \multicolumn{4}{|c|}{ FTOrs99 obesity receptor gene } \\
\hline Homozygous & $27(60.00 \%)$ & $30(57.69 \%)$ & 0.615 \\
\hline Heterozygous & $16(35.56 \%)$ & $17(32.69 \%)$ & \\
\hline Mutant & $2(4.44 \%)$ & $5(11.11 \%)$ & \\
\hline \multicolumn{4}{|c|}{ FTOrs 80 obesity receptor gene } \\
\hline Homozygous & $27(60.00 \%)$ & $24(46.15 \%)$ & 0.268 \\
\hline Heterozygous & $16(35.56 \%)$ & $22(42.31 \%)$ & \\
\hline Mutant & $2(4.44 \%)$ & $6(11.54 \%)$ & \\
\hline
\end{tabular}

Comparisons between different studied vitamin D (Table 2), estrogen (Table 3), and obesity receptors genes (Table 4) genotypes regarding the related investigated characteristics parameters of the non-osteoporotic and osteoporotic were done. Both Taq1 and APal vitamin $\mathrm{D}$ receptor genes in their two forms did not show any effect on the vit. D and calcium intake, and serum vit. D. While heterozygous types of the osteoporotic women carried both Taq1 and APal vitamin D receptor genes revealed significant slight decrease in the level of serum calcium (Table 2). The Xba1 estrogen receptor gene was identified only in a homozygous type. The heterozygoustypePvu11 estrogen receptor gene was associated with insignificant higher BMI in both nonosteoporotic and osteoporotic women compared to the homozygous (Table 3). Among the osteoporotic women, both the mutant types of the FTOrs 99 and 88 obesity receptor genes were associated with the significant highest value of BMI (Table 4). In addition, the mutant types of the FTOrs 99 obesity receptor genes were associated with the significant highest value of caloric intake, fat intake, and saturated fatty acid intake (SFAs). Moreover, among the non-osteoporotic women, both the heterozygous types of the FTOrs 99 and 88 obesity receptor genes were associated with the significant highest value of caloric intake and insignificant highest value of BMI, while the mutant types were associated with the significant highest value of saturated (SFAs) and monounsaturated fatty acid intake (MUFAs).

\section{Discussion}

The role of nutrition on bone health is currently very important research area. Important function of vitamin $\mathrm{D}$ is to control calcium homeostasis through increasing intestinal absorption, as well as calcium bone restoration, and reduce parathyroid hormone (PTH) [23].

Osteoporosis; a multifactorial illness characterized by a decrease in bone mineral density which increments the likelihood of bone fractures; is caused by calcium insufficiency, and its rate increments with age. It is known that mutations in the functional regions of vitamin $\mathrm{D}$ receptor gene will influence the metabolism of minerals particularly calcium and so bone metabolism [24].

However, in this study, no effect for these genes was observed on the levels of serum vitamin D. Zakiet al [25]. stated that obese Egyptian women carry polymorphic alleles showed significant lower levels of serum $25(\mathrm{OH}) \mathrm{D}$. As for the level of serum calcium, data of this study showed that the heterozygous types of the osteoporotic women carried both genes revealed a slight but significant decrease in the level of serum calcium when compared to the homozygous osteoporotic women. In this context, Rivera-Leon et al. [26] found that the TT genotype of TaqI VDR gene polymorphism was correlated with low levels of osteocalcin (OC) in overweight and obese subjects.

Estrogen receptor 1 has an important role in the maintenance of the skeletal system which has been proven in experimental mice, from which the gene was deleted from the specific bone cells and their precursors. Absence of the estrogen receptor in osteoblast progenitor and precursor cells influenced the periosteum, whereas their deficiency in differentiated osteoblasts, osteoclasts, and osteocytes come about in diminished cancellous bone mass [27]. The results of this study showed that the homozygous Xba1 receptors gene was identified in all the women either non-osteoporotic or osteoporotic which might indicate no direct relation to osteoporosis. In the evaluations on ER $\alpha$ gene XbaI polymorphism and COL1A1gene Sp1 polymorphism, it was reported that there was no distinction in terms of average BMD values, genotype, and allele frequencies among groups. However, Mondockova et al. [28] expressed that 
Table 2 Comparison between different studied vitamin D receptors genes genotypes regarding the related investigated parameters

\begin{tabular}{|c|c|c|c|c|c|c|}
\hline $\begin{array}{l}\text { Parameters } \\
N=97\end{array}$ & $\begin{array}{l}\text { Non-osteoporotic } \\
N=45\end{array}$ & & & $\begin{array}{l}\text { Osteoporotic } \\
N=52\end{array}$ & & \\
\hline \multirow[t]{2}{*}{ Taq1 vit. D receptor } & $\begin{array}{l}\text { Homozygous } \\
\text { No: } 26\end{array}$ & $\begin{array}{l}\text { Heterozygous } \\
\text { No: } 19\end{array}$ & $P$ & $\begin{array}{l}\text { Homozygous } \\
\text { No: } 34\end{array}$ & $\begin{array}{l}\text { Heterozygous } \\
\text { No: } 18\end{array}$ & $P$ \\
\hline & Mean \pm SD & Mean \pm SD & & Mean \pm SD & Mean \pm SD & \\
\hline Age (years) & $38.39 \pm 7.11$ & $38.68 \pm 9.05$ & 0.907 & $54.96 \pm 5.15$ & $53.41 \pm 5.61^{*} \#$ & 0.322 \\
\hline Weight (kg) & $79.34 \pm 20.21$ & $78.64 \pm 22.35$ & 0.885 & $81.52 \pm 12.80$ & $72.75 \pm 21.37$ & 0.135 \\
\hline Height (cm) & $157.69 \pm 4.42$ & $155.95 \pm 6.95$ & 0.229 & $155.62 \pm 4.77$ & $152.00 \pm 9.09^{* \#}$ & 0.156 \\
\hline $\mathrm{BMI} \mathrm{kg} / \mathrm{m}^{2}$ ) & $31.89 \pm 7.91$ & $31.96 \pm 9.93$ & 0.978 & $33.78 \pm 5.85$ & $31.77 \pm 1.07$ & 0.386 \\
\hline Vit D intake( ugg) & $7.22 \pm 1.80$ & $6.59 \pm 2.71$ & 0.622 & $5.81 \pm 2.04$ & $6.88 \pm .3 .24$ & 0.976 \\
\hline Serum vit. $D$ (ng/mL) & $25.53 \pm 8.60$ & $23.11 \pm 6.56$ & 0.389 & $23.18 \pm 9.25$ & $25.44 \pm 6.45$ & 0.410 \\
\hline Calcium intake( mg) & $689.13 \pm 25.80$ & $613.54 \pm 27.24$ & 0.164 & $604.17 \pm 28.58$ & $601.70 \pm 29.65^{* \#}$ & 0.515 \\
\hline Serum calcium (mg/dL) & $9.92 \pm 0.81$ & $9.28 \pm 0.67$ & 0.081 & $9.26 \pm .0 .77$ & $9.19 \pm .0 .59$ & $0.014^{*}$ \\
\hline \multirow[t]{2}{*}{ Apa1 vit. D receptor } & $\begin{array}{l}\text { Homozygous } \\
\text { No: } 36\end{array}$ & $\begin{array}{l}\text { Heterozygous } \\
\text { No: } 9\end{array}$ & $P$ & $\begin{array}{l}\text { Homozygous } \\
\text { No: } 33\end{array}$ & $\begin{array}{l}\text { Heterozygous } \\
\text { No: } 18\end{array}$ & $P$ \\
\hline & Mean \pm SD & Mean \pm SD & & Mean \pm SD & Mean \pm SD & \\
\hline Age (years) & $38.39 \pm 7.76$ & $39.24 \pm 9.24$ & 0.317 & $55.03 \pm 4.48$ & $53.48 \pm 6.62$ & 0.383 \\
\hline Weight (kg) & $75.35 \pm 2.04$ & $93.81 \pm 3.29$ & $0.036^{*}$ & $80.48 \pm 1.61$ & $73.86 \pm 1.70$ & 0.131 \\
\hline Height $(\mathrm{cm})$ & $156.57 \pm 5.26$ & $156.96 \pm 5.62$ & 0.245 & $153.94 \pm 6.75$ & $154.89 \pm 6.94^{* \#}$ & 0.814 \\
\hline $\mathrm{BMI} \mathrm{Kg} / \mathrm{m}^{2}$ ) & $30.67 \pm 7.94$ & $31.92 \pm 8.71$ & 0.056 & $34.28 \pm 8.44$ & $30.62 \pm 6.28$ & 0.107 \\
\hline Vit D intake( ug) & $6.20 \pm 1.47$ & $5.91 \pm 2.33$ & 0.632 & $6.16 \pm 2.48$ & $6.13 \pm 1.72$ & 0.621 \\
\hline Serum vit. $D$ (ng/mL) & $24.80 \pm 8.16$ & $24.54 \pm 7.84$ & 0.513 & $25.78 \pm 9.83$ & $21.11 \pm 3.62$ & 0.077 \\
\hline Calcium intake( mg) & $686.53 \pm 25.19$ & $618.77 \pm 27.63$ & 0.474 & $609.19 \pm 24.35$ & $607.49 \pm 29.31$ & 0.172 \\
\hline Serum calcium (mg/dL & $9.61 \pm 0 . .60$ & $9.32 \pm 0.62$ & 0.332 & $9.14 \pm 0.52$ & $9.08 \pm 0.59$ & $0.010^{*}$ \\
\hline
\end{tabular}

$B M I$ body mass index, vit. $D$ Vitamin $D$

${ }^{*} P<0.05$ homozygous vs. heterozygous

$\# P<0.05$ non-osteoporotic vs. osteoporotic

Table 3 Comparison between different studied estrogen receptors genes genotypes regarding the related investigated parameters

\begin{tabular}{|c|c|c|c|c|c|c|}
\hline $\begin{array}{l}\text { Parameters } \\
N=97\end{array}$ & $\begin{array}{l}\text { Non-osteoporotic } \\
N=45\end{array}$ & & & $\begin{array}{l}\text { Osteoporotic } \\
N=52\end{array}$ & & \\
\hline \multirow[t]{2}{*}{ Taq1 vit. D receptor } & $\begin{array}{l}\text { Homozygous } \\
\text { No: } 26\end{array}$ & $\begin{array}{l}\text { Heterozygous } \\
\text { No: } 19\end{array}$ & $P$ & $\begin{array}{l}\text { Homozygous } \\
\text { No: } 34\end{array}$ & $\begin{array}{l}\text { Heterozygous } \\
\text { No: } 18\end{array}$ & $P$ \\
\hline & Mean \pm SD & Mean \pm SD & & Mean \pm SD & Mean \pm SD & \\
\hline \multirow[t]{2}{*}{ Xba1 estrogen receptors } & $\begin{array}{l}\text { Homozygous } \\
\text { No: } 45\end{array}$ & $\begin{array}{l}\text { Heterozygous } \\
\text { No: } 0.0\end{array}$ & & $\begin{array}{l}\text { Homozygous } \\
\text { No: } 52\end{array}$ & $\begin{array}{l}\text { Heterozygous } \\
\text { No: } 0.0\end{array}$ & \\
\hline & Mean \pm SD & Mean \pm SD & & Mean \pm SD & Mean \pm SD & \\
\hline Age (years) & $38.55 \pm 7.97$ & $38.68 \pm 9.05$ & 0.907 & $54.39 \pm 5.30^{*}$ & $53.41 \pm 5.61^{*}$ & 0.322 \\
\hline Weight (kg) & $79.04 \pm 2.41$ & $78.64 \pm 22.35$ & 0.885 & $78.48 \pm 1.66$ & $72.75 \pm 21.37$ & 0.135 \\
\hline Height $(\mathrm{cm})$ & $156.96 \pm 5.62$ & $155.95 \pm 6.95$ & 0.229 & $154.37 \pm 6.73^{*}$ & $152.00 \pm 9.09^{*}$ & 0.156 \\
\hline $\mathrm{BMI}\left(\mathrm{kg} / \mathrm{m}^{2)}\right.$ & $31.92 \pm 8.71$ & $31.96 \pm 9.93$ & 0.978 & $33.08 \pm 7.83$ & $31.77 \pm 1.07$ & 0.386 \\
\hline \multirow[t]{2}{*}{ Pvu11 estrogen receptor } & $\begin{array}{l}\text { Homozygous } \\
\text { No: } 32\end{array}$ & $\begin{array}{l}\text { Heterozygous } \\
\text { No: } 13\end{array}$ & $P$ & $\begin{array}{l}\text { Homozygous } \\
\text { No: } 35\end{array}$ & $\begin{array}{l}\text { Heterozygous } \\
\text { No: } 17\end{array}$ & $P$ \\
\hline & Mean \pm S D & Mean \pm SD & & Mean \pm SD & Mean \pm SD & \\
\hline Age (years) & $38.20 \pm 7.13$ & $39.40 \pm 1.01$ & 0.638 & $54.19 \pm 6.11$ & $54.81 \pm 3.18^{*} \#$ & 0.657 \\
\hline Weight (kg) & $75.94 \pm 2.07$ & $86.68 \pm 3.07$ & 0.193 & $77.58 \pm 1.50$ & $80.35 \pm 1.98$ & 0.538 \\
\hline Height $(\mathrm{cm})$ & $156.62 \pm 4.36$ & $157.77 \pm 8.11$ & 0.649 & $154.37 \pm 5.52$ & $154.35 \pm 8.92^{*} \#$ & 0.904 \\
\hline BMI $\left(\mathrm{kg} / \mathrm{m}^{2}\right)$ & $30.86 \pm 7.96$ & $34.53 \pm 1.02$ & 0.205 & $32.53 \pm 6.23$ & $34.21 \pm 1.05$ & 0.474 \\
\hline
\end{tabular}

$B M I$ body mass index

$\# P, 0.05$ non-osteoporotic vs. osteoporotic 
Table 4 Comparison between different studied obesity receptors genes genotypes regarding the related investigated parameters

\begin{tabular}{|c|c|c|c|c|c|c|c|c|}
\hline $\begin{array}{l}\text { Parameters } \\
N=97\end{array}$ & $\begin{array}{l}\text { Non-osteopor } \\
N=45\end{array}$ & & & & $\begin{array}{l}\text { Osteoporotic } \\
N=52\end{array}$ & & & \\
\hline \multirow[t]{2}{*}{$\begin{array}{l}\text { FTOrs99 obesity } \\
\text { receptor }\end{array}$} & $\begin{array}{l}\text { Homozygous } \\
\text { No: } 27\end{array}$ & $\begin{array}{l}\text { Heterozygous } \\
\text { No: } 16\end{array}$ & $\begin{array}{l}\text { Mutant } \\
\text { No: } 2\end{array}$ & $P$ & $\begin{array}{l}\text { Homozygous } \\
\text { No: } 30\end{array}$ & $\begin{array}{l}\text { Heterozygous } \\
\text { No: } 17\end{array}$ & $\begin{array}{l}\text { Mutant } \\
\text { No: } 5\end{array}$ & $P$ \\
\hline & Mean \pm SD & Mean \pm SD & Mean \pm SD & & Mean \pm SD & Mean \pm SD & Mean \pm SD & \\
\hline Age (years) & $36.65 \pm 8.01 \#$ & $41.75 \pm 7.17$ & $38.63 \pm 9.75$ & 0.134 & $55.20 \pm 4.68 \#$ & $51.93 \pm 5.91+$ & $57.92 \pm 3.77$ & $0.040^{*}$ \\
\hline Weight (kg) & $74.12 \pm 2.71$ & $87.61 \pm 1.53$ & $77.00 \pm 3.47$ & 0.183 & $79.82 \pm 1.57$ & $74.11 \pm 1.79$ & $85.32 \pm 1.63$ & 0.283 \\
\hline Height (cm) & $157.30 \pm 6.01$ & $157.19 \pm 4.32$ & $150.50 \pm 9.19$ & 0.234 & $155.17 \pm 5.52$ & $\begin{array}{l}155.18 \pm \\
6.85+\end{array}$ & $146.80 \pm 9.44 @$ & $0.027^{*}$ \\
\hline BMI $\left(\mathrm{kg} / \mathrm{m}^{2)}\right.$ & $29.77 \pm 9.67 \#$ & $35.38 \pm 5.54$ & $33.24 \pm 3.12$ & 0.120 & $33.18 \pm 6.44$ & $30.62 \pm 6.88+$ & 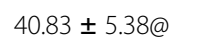 & $0.034^{*}$ \\
\hline Caloric intake (Cal) & $\begin{array}{l}1655.93 \pm \\
28.75 \#\end{array}$ & $2483.73 \pm 26.19$ & $2150.64 \pm 8.76$ & $0.007^{* *}$ & $\begin{array}{l}2684.63 \pm \\
37.69 \#\end{array}$ & $\begin{array}{l}2711.63 \pm \\
31.15\end{array}$ & $2720.13 \pm 39.54$ & $0.030^{*}$ \\
\hline Fat intake (g) & $85.71 \pm 2.97$ & $90.55 \pm 8.26$ & $114.18 \pm 13.61$ & 0.554 & $132.38 \pm 15.54 \#$ & $134.25 \pm 13.34$ & $135.14 \pm 14.50$ & $0.017^{*}$ \\
\hline SFAs $(g)$ & $25.57 \pm 16.01 \#$ & $32.88 \pm 12.95$ & $37.21 \pm 8.70$ & $0.002^{* *}$ & $44.67 \pm 17.21 \#$ & $46.14 \pm 15.82$ & $47.30 \pm 15.46$ & $0.014^{*}$ \\
\hline MUSFAs (g) & $18.73 \pm 16.02 \#$ & $20.34 \pm 13.78$ & $20.96 \pm 2.78$ & $0.005^{* *}$ & $32.75 \pm 16.12 \#$ & $31.72 \pm 20.04$ & $31.36 \pm 14.69$ & 0.114 \\
\hline PUSFAs (g) & $18.83 \pm 18.45 \#$ & $21.85 \pm 13.41$ & $20.44 \pm 14.74$ & 0.072 & $30.23 \pm 18.48$ & $31.64 \pm 8.95$ & $29.63 \pm 15.04$ & 0.329 \\
\hline \multirow[t]{2}{*}{$\begin{array}{l}\text { FTOrs } 80 \text { obesity } \\
\text { receptor }\end{array}$} & $\begin{array}{l}\text { Homozygous } \\
\text { No: } 27\end{array}$ & $\begin{array}{l}\text { Heterozygous } \\
\text { No: } 16\end{array}$ & $\begin{array}{l}\text { Mutant } \\
\text { No: } 2\end{array}$ & $P$ & $\begin{array}{l}\text { Homozygous } \\
\text { No: } 24\end{array}$ & $\begin{array}{l}\text { Heterozygous } \\
\text { No: } 22\end{array}$ & $\begin{array}{l}\text { Mutant } \\
\text { No: } 6\end{array}$ & $P$ \\
\hline & Mean \pm SD & Mean \pm SD & Mean \pm SD & & Mean \pm SD & Mean \pm SD & Mean \pm SD & \\
\hline Age (years) & $36.65 \pm 8.015 \#$ & $41.75 \pm 7.17 \#$ & $38.63 \pm 9.75$ & 0.134 & $55.28 \pm 4.86$ & $52.48 \pm 5.62+$ & $57.84 \pm 3.38^{*}$ & 0.051 \\
\hline Weight (kg) & $74.12 \pm 2.71$ & $87.61 \pm 1.53$ & $77.00 \pm 3.47$ & 0183 & $77.15 \pm 1.57$ & $77.58 \pm 1.78$ & $87.13 \pm 1.52$ & 0.389 \\
\hline Height (cm) & $157.30 \pm 6.01$ & $157.19 \pm 4.32$ & $150.50 \pm 9.19$ & 0.234 & $154.46 \pm 5.47$ & $\begin{array}{l}156.09 \pm \\
6.57+\end{array}$ & 147.67 ×8.71@ & $0.027^{*}$ \\
\hline BMI $\left(k / m^{2}\right)$ & $29.77 \pm 9.67 \#$ & $35.38 \pm 5.54 \#$ & $33.24 \pm 2.12$ & 0.120 & $32.40 \pm 6.66$ & $31.67 \pm 6.60+$ & $40.96 \pm 4.23^{@}$ & $0.027^{*}$ \\
\hline Caloric intake (Cal) & $\begin{array}{l}1655.93 \pm \\
28.75 \#\end{array}$ & $\begin{array}{l}2483.76 \pm \\
26.19 \#\end{array}$ & $\begin{array}{l}2450.65 \pm \\
28.76\end{array}$ & $0.007^{* *}$ & $2265.28 \pm 29.75$ & $\begin{array}{l}2625.97 \pm \\
28.69\end{array}$ & $\begin{array}{l}2711.85 \pm \\
26.91^{*}\end{array}$ & 0.314 \\
\hline Fat intake (g) & $90.55 \pm 8.26$ & $114.18 \pm 3.61$ & $118.71 \pm 2.97$ & 0.554 & $120.43 \pm 4.86$ & $129.79 \pm 5.97$ & $131.90 \pm 3.31$ & 0.137 \\
\hline SFAs (g) & $20.57 \pm 16.01 \#$ & $36.88 \pm 12.95 \#$ & $38.21 \pm 8.70$ & $0.002^{* *}$ & $36.14 \pm 16.98$ & $44.46 \pm 18.47$ & $46.76 \pm 14.23^{*}$ & 0.182 \\
\hline MUSFAs (g) & $18.73 \pm 6.02 \#$ & $25.34 \pm 13.78$ & $25.96 \pm 10.78$ & $0.005^{* *}$ & $26.84 \pm 11.02$ & $30.12 \pm 11.13$ & $29.69 \pm 10.70^{*}$ & 0.481 \\
\hline PUSFAs (g) & $18.83 \pm 4.45 \#$ & $21.85 \pm 10 . \# 41$ & $22.44 \pm 11.74$ & 0.072 & $24.37 \pm 10.72$ & $29.58 \pm 11.14$ & $25.06 \pm 7.24^{*}$ & 0.491 \\
\hline
\end{tabular}

BMI body mass index, SFAs saturated fatty acids, MUSFAs mono unsaturated fatty acids, PUSFAs poly unsaturated fatty acids

"Significant differences between homo and hetero

tSignificant differences between hetero and mutant

${ }^{\circledR}$ Significant differences between mutant and homo

decreased BMD in postmenopausal women may be linked to the Xba1 polymorphism. The homozygous estrogen receptor gene Pvu11 was slightly more prevalent among non-osteoporotic women, while its polymorph heterozygous was found slightly more among osteoporotic participants $(32.69 \%$ of the osteoporotic compared to $28.89 \%$ of the non-osteoporotic women). It was assigned in postmenopausal women that ER $\alpha$ gene PvuII polymorphism was effective on the BMD values of the lumbar vertebra [29].

It was already accepted that obesity and osteoporosis were two different diseases, but later researches have revealed that both diseases share many common genetic and environmental factors [30]. Genetic inclination to weight gain may have connecting with an obesogenic environment. Developing researchers have found that changes in adiposity and metabolic reaction to low-calorie weight diets may well be altered by hereditary variations related to weight gain, metabolic condition and inclination to some kinds of foods [31]. Current study revealed that both the mutant types of the FTOrs 99 and 88 obesity receptor genes were associated with the highest value of BMI and also higher intake of calories, fat and saturated fatty acid (SFAs), which were more prominent among the osteoporotic women. Franzago et al. (2020) reported that nutrition may be a modifiable key that is able to be associated with both the genome and epigenome to impact the health of the human being. In specific, dietary components, nutrient requirements, and the diet itself are able to modulate gene expression [32].

\section{Conclusion}

Osteoporosis was high among women had dominant Taq1 vitamin D receptor gene, while it was less 
prevalent among women had homozygous Apal receptor gene. However, both genes had no effect on either vitamin $\mathrm{D}$ or calcium intake, or the serum level of vitamin D. Yet, the osteoporotic women carried heterozygous types of both genes revealed a slight but significant decrease in the level of serum calcium. This may be due to the lack of calcium absorption among them, which need to increase their awareness to increase their intake of calcium rich foods. The mutant genotypes FTOrs99 and FTOrs 80 obesity receptor genes might predispose to significant genetic variation in the intake of calories and fat; especially the saturated fatty acids; plus the BMI status. Based on these results, these people should be instructed to avoid or decrease the consumption of such foods and in addition reduce their weight.

\section{Abbreviations}

BMD: Bone mass density; BMI: Body mass index; ESR1, ESR2: Estrogen receptor genes; Ht: Body height; GWASs: Genome-wide association's studies; OC: Osteocalcin; SFAs: Saturated fatty acid; SPSS: Statistical Package for Social Sciences; WFDAS: World Food Dietary Assessment System; WT: Body weight; VDR: Vitamin D receptor (VDR); (25 (OH) D): Serum 25 hydroxy vitamin-D

\section{Acknowledgements}

We would like to acknowledge our institute, National Research Centre, Egypt; without its fund, this study could not be done. Authors are also grateful to everybody participated in this study; the employers of our institute who were the participants of this study, the technicians who helped in the laboratory analysis, and the doctors who participated in the collection of the data. Without their help, this study could not have been completed.

\section{Authors' contributions}

N.E. contributed to the acquisition of funding, general supervision of the research group, and gave conceptual advice. S.M. is the nutritional consultant and wrote draft of the manuscript. S.A. shared in tabulation of the data and publication process. N.H. performed the statistical analysis. Gh.N. is responsible about genetic analysis. E.A. performed laboratory analysis. A.Kh. performed DEXA Scan and the anthropology measurements. M.M, Kh.M, and M.A.S. collected the nutritional data from participants and taken anthropology measurements. All authors read and have approved the submitted version. They have agreed both to be personally accountable for the authors' own contributions and to ensure that questions related to the accuracy or integrity of any part of the work, even ones in which the authors were not personally involved, are appropriately investigated, resolved, and the resolution documented in the literature.

\section{Funding}

This research paper was derived from a project funded by National Research Centre (NRC) Egypt, 2016-2019 entitled "Bone mass among Overweight and Obese Women: Mechanism and Intervention" (11th Research Plan of the NRC), as part of our jobs.

\section{Availability of data and materials}

The datasets used and/or analyzed during the current study are available from the corresponding author on reasonable request, after taking the permission of our institute "National Research Centre."

\section{Ethics approval and consent to participate}

A written informed consent was obtained from all participants after being informed about the purpose of the study. This research paper was derived from a cross-sectional survey of a project funded by National Research Centre (NRC) Egypt, 2016-2019 entitled "Bone mass among Overweight and Obese Women: Mechanism and Intervention."( $11^{\text {th }}$ Research Plan of the NRC), with an approval obtained from Ethics Committee of NRC (Registration Number is $16 / 127)$.

\section{Consent for publication}

Not applicable.

\section{Competing interests}

The authors declare that there are no financial and personal relationships with other people or organizations that could inappropriately influence (bias) the present work.

\section{Author details}

'Biological Anthropology Department, Medical Research Division, National Research Centre, Giza, Egypt. 'Nutrition and Food ScienceDepartment, National Research Centre, Giza, Egypt. ${ }^{3}$ Molecular Genetics and Enzymology Department, National Research Centre, Giza, Egypt. ${ }^{4}$ Clinical and Chemical Pathology Department, Medical Research Division, National Research Centre, Giza, Egypt.

Received: 8 June 2020 Accepted: 26 January 2021

Published online: 09 February 2021

\section{References}

1. Duncan EL, Danoy P, Kemp JP, Leo PJ, McCloskey E, Nicholson GC et al (2011) Genome-wide association study using extreme truncate selection identifies novel genes affecting bone mineral density and fracture risk. Plos Genet. 7(4):e1001372

2. Wang C, Zhang Z, Zhang H, He JW, Gu JM, Hu WW, Hu YQ, Li M, Liu YJ, Fu WZ, Yue H, Ke YH, Zhang ZL (2012) Susceptibility genes for osteoporotic fracture in postmenopausal Chinese women. J Bone Miner Res. 27(12):25822591

3. Jean G, Souberbielle JC (2017) Chazot C3. Vitamin D in Chronic Kidney Disease and Dialysis Patients. Nutrients 9(4):328. https://doi.org/10.3390/ nu9040328

4. Holick MF (2007) Vitamin D deficiency. N Engl J Med. 357(3):266-281

5. Haussler MR, Whitfield GK, Kaneko I et al (2013) Molecular mechanisms of vitamin D action. Calcif Tissue Int. 92(2):77-98

6. Pike JW, Meyer MB (2014) Fundamentals of vitamin D hormone-regulated gene expression. J Steroid BiochemMol Biol 144(Pt A):5-11

7. Cauley JA (2015) Estrogen and bone health in men and women. Steroids 99(Pt A):11-15

8. Mitek T, Nagraba Ł, Deszczyński J, Stolarczyk M, Kuchar E, Stolarczyk A (2019) Genetic predisposition for osteoporosis and fractures in postmenopausal women. AdvExp Med Biol. 1211:17-24

9. Gennari L, Merlotti D, De Paola V, Calabró A, Becherini L, Martini G, Nuti R (2005) Estrogen receptor gene polymorphisms and the genetics of osteoporosis: a HuGE review. Am J Epidemiol. 161(4):307-320

10. Gennari L, De Paola V, Merlotti D, Martini G, Nuti R (2007) Steroid hormone receptor gene polymorphisms and osteoporosis: a pharmacogenomic review. Expert OpinPharmacother. 8(5):537-553

11. Saoji R, Desai M, Das RS, Das TK, Khatkhatay MI (2019) Estrogen receptor a and $\beta$ gene polymorphism in relation to bone mineral density and lipid profile in Northeast Indian women. Gene. 20(710):202-209

12. Salamat MR, Salamat AH, Janghorbani M (2016) Association between obesity and bone mineral density by gender and menopausal status. Endocrinology and Metabolism. 31(4):547-558

13. Kaji H (2013) Linkage between muscle and bone: common catabolic signals resulting in osteoporosis and sarcopenia. Current opinion in clinical nutrition and metabolic care. 16(3):272-277

14. Bhupathiraju SN, Dawson-Hughes B, Hannan MT, Lichtenstein AH, Tucker KL (2011) Centrally located body fat is associated with lower bone mineral density in older Puerto Rican adults. The American journal of clinical nutrition. 94(4):1063-1070

15. Scott D, Chandrasekara SD, Laslett LL, Cicuttini F, Ebeling PR, Jones G (2016) Associations of sarcopenic obesity and dynapenic obesity with bone mineral density and incident fractures over 5-10 years in communitydwelling older adults. Calcified tissue international. 99(1):30-42

16. Chung JH, Hwang HJ, Shin HY, Han CH (2016) Association between Sarcopenic Obesity and Bone Mineral Density in Middle-Aged and Elderly Korean. Annals of nutrition \& metabolism. 68(2):77-84

17. Hu Y, Tan LJ, Chen XD, Liu Z, Min SS, Zeng Q, Shen H, Deng HW (2018) Identification of novel potentially pleiotropic variants associated with osteoporosis and obesity using the cFDR method. J ClinEndocrinolMetab 103(1):125-138 
18. Hiernaux J, Tanner JM. Growth and physical studies. In: Human Biology: guide to field methods. Eds. Weiner J.S., Lourie S.A., IBP. London, Blackwell Scientific Publications: Oxford, 1969.

19. World Health Organ (2003) Prevention and management of osteoporosis. Tech Rep Ser. 921:1-164

20. Külpmann WR Determination of electrolytes in serum and plasma].Wien Klin Wochenschr Suppl. 1992; 192:37-41.PMID: 1502823 Review. German.

21. He C-S, Gleeson M, Fraser WD (2013) Measurement of circulating 25hydroxy vitamin D using three commercial enzyme-linked immunosorbent assay kits with comparison to liquid chromatography: tandem mass spectrometry method. ISRN Nutr 2013:723139. Published online 2013 Aug 13. https://doi.org/10.5402/2013/723139

22. World Food Dietary Assessment System, (WFDAS), 1995, USA, University of California.

23. Byrd-Bredbenner C, Moe G, Beshgetoor D, Berning J (2013) Wardlaw's perspectives in nutrition. 9. McGraw-Hill, New York

24. Dabirnia R, Mahmazi S, Taromchi A, Nikzad M, Saburi E (2016) The relationship between vitamin $\mathrm{D}$ receptor (VDR) polymorphism and the occurrence of osteoporosis in menopausal Iranian women. Clin Cases Miner Bone Metab 13(3):190-194

25. Zaki M, Kamal S, Basha WA, Youness E, Ezzat W, El-Bassyouni H, Amr K (2017) Association of vitamin D receptor gene polymorphism (VDR) with vitamin D deficiency, metabolic and inflammatory markers in Egyptian obese women. Genes Dis 4(3):176-182

26. Rivera-Leon EA, Palmeros-Sanchez B, Llamas-Covarrubias IM, Fernandez S, Armendariz-Borunda J, Gonzalez-Hita M, Bastidas-Ramirez BE, ZepedaMoreno A, Sanchez-Enriquez S (2015) Vitamin-D receptor gene polymorphisms (Taql and Apal) and circulating osteocalcin in type 2 diabetic patients and healthy subjects. Endokrynol Pol. 66(4):329-333

27. Rooney AM, Meulen VD (2017) MCH. Mouse models to evaluate the role of estrogen receptor a in skeletal maintenance and adaptation. Ann N Y Acad Sci. 1410(1):85-92

28. Mondockova M, Adamkovicova M, Lukacova M, Grosskopf B, Babosova R, Galbavy D, Martiniakova M, Omelka R (2018) The estrogen receptor 1 gene affects bonemineral density and osteoporosis treatment efficiency in Slovak postmenopausal women. BMC Med Genet 19:174

29. Erdogan MO, Yıldız H, Artan S, Solak M, Taşcıoğlu F, Dündar U, Eser B, Colak E (2011) Association of estrogen receptor alpha and collagen type I alpha 1 gene polymorphisms with bone mineral density in postmenopausal women. Osteoporosint 22:1219-1225

30. Zhao LJ, Jiang H, Papasian CJ, Maulik D, Drees B, Hamilton J, Deng HW (2008) Correlation of obesity and osteoporosis: effect of fat mass on the determination of osteoporosis. J Bone Miner Res 23(1):17-29

31. Heianza Y, Qi L (2017) Gene-Diet Interaction and Precision Nutrition in Obesity. Int J Mol Sci. 18(4):787

32. Franzago M, Santurbano D, Vitacolonna E, Stuppia L (2020) Genes and diet in the prevention of chronic diseases in future generations. Int J Mol Sci. 21(7):2633

\section{Publisher's Note}

Springer Nature remains neutral with regard to jurisdictional claims in published maps and institutional affiliations.

\section{Submit your manuscript to a SpringerOpen ${ }^{\circ}$ journal and benefit from:}

- Convenient online submission

- Rigorous peer review

- Open access: articles freely available online

- High visibility within the field

- Retaining the copyright to your article

Submit your next manuscript at $\boldsymbol{\nabla}$ springeropen.com 